\title{
Theory of the Novel: The Literary Imagination of Classical Film Theory*
}

\section{JOHANNES VON MOLTKE}

In the fall of 1921, the Viennese social reformer Eugenie Schwarzwald approached a young Hungarian émigré with a proposition: Mariette Lydis, a friend of Schwarzwald's, had created a set of watercolors, and now the two of them were looking for someone to write a collection of fairy tales to accompany the images in a book publication. The young author, Béla Balázs, agreed, and he penned sixteen tales in the space of three weeks. The book was published under the title Der Mantel der Träume (The cloak of dreams).

A few years later, the Frankfurter Zeitung began running a serialized novel by a curiously anonymous author: Ginster: Von ihm selbst geschrieben (Gorse: Written by himself) was the title, and the novel made a splash. By the time it was published in book form by the prestigious Fischer Verlag in the fall of 1928, however, most interested readers would have divined the author's identity: barely concealed behind the smoke screens of fictionalization, anonymization, pseudonyms, and newspaper bylines was none other than Siegfried Kracauer, himself an editor and film critic at the Frankfurter Zeitung. Forced into exile in 1933, Kracauer would go on to write a second novel, Georg, a sequel of sorts, during his Paris years. This time, all indications were that he would publish under his own name-but in the hardships of emigration that ultimately led him to the United States, Kracauer failed to secure a contract, and the novel was only published posthumously by Suhrkamp in 1970 .

A similar fate befell another exile who, on July 13, 1940, in London, completed the final page of a typescript entitled Eine verkehrte Welt (A topsy-turvy world), a novel of the fantastic (ein phantastischer Roman) on which he had been working during the 1930s in Italy and England. In the turbulent years of war and emigration, it would take another decade before the young author, now in the USA, would secure a contract for the novel with the German publisher Curt

\footnotetext{
* This article was prompted by the first Berkeley Conference on Silent Cinema, held in 2011 and devoted to "Cinema Across Media." I am grateful to the organizers of that event for including the initial version, which I subsequently developed with the help of incisive comments from Dana Polan and my colleagues Kerstin Barndt, Andreas Gailus, and Julia Hell. I am grateful, as well, to the editors of October for their useful feedback during the editorial process. Unless indicated otherwise, all translations from the German are my own.
} 
Weller. As luck would have it, the latter went bankrupt while the book was in production; only half a century later would a small publishing house in Cologne pick up the manuscript again. By the time Eine verkehrte Welt appeared in 1997, its author-Rudolf Arnheim-was well into his nineties.

$* * *$

A beautifully illustrated collection of Orientalist fairy tales; a pseudo-biographical novel in a mildly satirical mode; and an allegorical piece of science fiction that holds up an inverted mirror to a Western civilization already in disarray: generically and stylistically, these three texts have little to do with one another-or so it would appear, if their authors did not form a rather well-defined trio, whose close relations would have been readily apparent to readers with an interest in cinema: to film scholars, Béla Balázs, Siegfried Kracauer, and Rudolf Arnheim remain well known to this day as pioneers of what we now consider "classical film theory." Setting out as brilliant young critics of the equally young medium (each of them a consummate stylist in his own right), they were acquainted with each other's influential articles in the leading papers of Vienna, Frankfurt, and Berlin; and although they began from distinct premises and arrived at divergent conclusions, they would continue to acknowledge, cite, and review each other's work, going on in a more theoretical mode to dilate on cinematic technique and style, the medium's relationship to folk art, its form-giving powers, and its redemptive realism.

To be sure, there are important differences between Arnheim's formalism, for example, and Kracauer's realism; ${ }^{1}$ or between Balázs's romantic interpretation of the close-up of a face as a conduit to the soul and Arnheim's modernist enthusiasm for the close-up as an alienating perceptual effect. But historical distance also permits a synoptic view of classical film theory as a relatively unified affair, one in which our trio is comfortably aligned with respect to shared goals and assumptions. From such a historicizing perspective, which has been gaining ground among scholars and critics in recent years, ${ }^{2}$ at least three com-

1. This distinction is intimated in Kracauer's own assertion, in the preface to Theory of Film, that "my book differs from most writings in the field in that it is a material aesthetics, not a formal one." Siegfried Kracauer, Theory of Film (Princeton: Princeton University Press, 2007), p. xlix (emphasis in original); it was subsequently cemented in Dudley Andrew's influential The Major Film Theories (Oxford: Oxford University Press, 1976). The realism/formalism divide has served since then as the structuring template for virtually all subsequent accounts of classical film theory, with the notable exception of Malcolm Turvey's recent critique in Doubting Vision: Film and the Revelationist Tradition (Oxford: Oxford University Press, 2008).

2. Eric Rentschler points out that already in 1981, Karsten Witte had "described Arnheim, Balázs, and Kracauer as the 'ABKs' of German film theory, a formulation that suggests we might productively consider them as a collective corpus rather than as embodiments of altogether different perspectives." "Rudolf Arnheim's Early Passage Between Social and Aesthetic Film Criticism," in Arnheim for Film and Media Studies, Scott Higgins, ed. (New York: Routledge, 2010), p. 62. To the example of the three authors with which this article is concerned, we should add that of André Bazin. Recent scholarly activ- 
monalities emerge: first, these three thinkers jointly aspired, along with a host of other classical film theorists, to vindicate cinema as an art form on par with the other arts (consider the title of Arnheim's seminal Film as Art). Second, above and beyond their distinct affinities with "modernism" or "formalism" on the one hand and "realism" on the other, they shared an investment in what Malcolm Turvey has usefully described as the "revelationist" strain of classical film theory: each of these theorists was drawn to the new medium for its ability to overcome the perceived shortcomings of human vision-in Kracauer's words, to "reveal things normally unseen."3 Third, given their background in the humanistic canon of European letters, they shared a number of premises drawn from classical aesthetics. In particular, as Noël Carroll has demonstrated by subjecting important texts by the classical film theorists to analytical critique, virtually all of classical film theory espoused what he calls the "medium-specificity thesis." According to this thesis, which dates back to Lessing's Laocoön treatise, "each art form, in virtue of its medium, has its own exclusive domain of development." 4 Carroll has argued persuasively that this line of thinking regularly accompanies the rise of new media such as film, photography, and video, whose status as art it ostensibly helps to legitimize-in other words, the shared espousal of the medium-specificity thesis relates directly to the shared impulse to legitimize film as art.

Carroll has serious misgivings about the validity of this thesis on analytic-philosophical grounds, calling it fallacious to either construe a medium's limitations and possibilities as normative for that medium or assert the existence of a causal connection between style and ontology. This argument has clear merit and is worth

ities in this area include the fact that Béla Balázs's major works, as well as his fairy tales, are now available for the first time in English translation, and conferences at Harvard, Yale, Paris, and Dartmouth have led to anthologies taking up "Arnheim for film and media studies," "opening Bazin" for reconsideration, and probing Kracauer's legacies. See Béla Balázs, Early Film Theory: Visible Man and The Spirit of Film, ed. Erica Carter, trans. Rodney Livingstone (New York: Berghahn, 2010); Béla Balázs, The Cloak of Dreams: Chinese Fairy tales, trans. Jack Zipes (Princeton: Princeton University Press, 2010); Arnheim for Film and Media Studies, ed. Scott Higgins (New York: Routledge, 2010); Opening Bazin: Postwar Film Theory and Its Afterlife, ed. Dudley Andrew with Hervé Joubert Laurencin (Oxford: Oxford University Press, 2011); Culture in the Anteroom: The Legacies of Siegfried Kracauer, ed. Gerd Gemünden and Johannes von Moltke (Ann Arbor: University of Michigan Press, 2012); as well as an edition of Siegfried Kracauer's American Writings: Essays on Film and Popular Culture, ed. Johannes von Moltke and Kristy Rawson (Berkeley: University of California Press, 2012).

3. Kracauer, Theory of Film, p. 46. On the "revelationist tradition" in classical film theory, see Turvey, Doubting Vision. Turvey occasionally appears to exclude the "modernist" Arnheim from this tradition, but as he himself rightly points out, the "revelationist" interest in the cinema tends to subsume the modernist/realist dialectic. Turvey further differentiates his arguments in "Arnheim and Modernism," in Arnheim for Film and Media Studies, pp. 31-49.

4. Noël Carroll, "The Specificity of Media in the Arts," in Theorizing the Moving Image (Cambridge: Cambridge University Press, 1996), p. 25. See also "Medium Specificity Arguments and the SelfConsciously Invented Arts: Film, Video, and Photography," in the same volume, pp. 3-24. Kracauer, for example, formulates the medium-specificity thesis at the outset of his Theory of Film: "This study rests upon the assumption that each medium has a specific nature which invites certain kinds of communications while obstructing others," p. 3. 
debating on its own terms, ${ }^{5}$ but there is also a sense in which Carroll's trenchant logical critique misses the point, imposing standards of academic rigor and logical coherence that are at odds with the rather more broadly defined forms of humanistic inquiry that these thinkers pursued during the silent era and beyond. ${ }^{6}$ Here, the classical theorists' turn to literary fiction becomes significant—not for being any less rigorous than their critical writings, but for bringing that rigor to bear on the (literary) imagination rather than on (formal) logic, and, perhaps even more important, for pursuing questions of cinematic specificity in the medium of literature. ${ }^{7} \mathrm{~A}$ rereading of the above-mentioned texts, in other words, gives rise to a lingering suspicion concerning Carroll's argument: if these thinkers were indeed wedded to the notion of medium specificity, how do we account for what we might call their media promiscuity, which combined a love for the cinema with attentive criticism and a theoretical defense of the medium, as well as with an urge to try their hands at various literary genres? ${ }^{8}$ (This is not even to mention Balázs's forays into opera, or Arnheim's later turn to art history.) As I will show, there is a substantive give-andtake between these theorists' fairy tales and novels, on the one hand, and the theories they construed, on the other. This prose work, in other words, went hand in hand with the elaboration of the central positions in classical film theory, which the novels help in turn to elucidate.

A closer look at these texts quickly reveals their cinematic qualities. Expressionist cinema's nightmare scenarios, silent melodramas' pathos, and espe-

5. In a penetrating analysis of André Bazin's theories of cinematic realism, Daniel Morgan has offered a rejoinder to Carroll, arguing that the medium-specificity thesis may be construed in terms other than the direct, causal link between the "nature" or essence of film and its attendant stylistic options (whether realist or modernist). Following Michael Fried, Morgan proposes that, rather than dispense with the ontological or essentialist arguments of the classical film theorists, we think of style as a way of acknowledging-even if by negation - the specificity of a given medium's constitution. Rather than following necessarily from the photographic nature of cinema, realism as discussed by Bazin or Kracauer should be understood, according to Morgan, as one of various ways to acknowledge the ontology of the photographic image at the level of style. Daniel Morgan, "Rethinking Bazin: Ontology and Realist Aesthetics," Critical Inquiry 32 (Spring 2006), pp. 443-81. For a differently situated argument for reconsidering classical film theory's notions of medium specificity, see Mary Ann Doane, "The Indexical and the Concept of Medium Specificity," Differences 18, no. 1 (2007), pp. 128-52.

6. "By philosophical standards," Miriam Hansen concedes, "Kracauer's mode of analysis sometimes appears slippery and inconsistent, if not contradictory." But unlike Carroll, Hansen proceeds to inquire into the payoff, rather than only into the logical flaws, of the kinds of figurative, rhetorical, and stylistic devices that Kracauer deploys: "What ensures continued fascination with Kracauer's texts is that they are suffused with another kind of logic, a style of theorizing that we might call writerly or poetic. Kracauer argues as much through images and tropes, through figures of chiasmus, paradox, understatement and literalization, as through analytic reasoning and allegorical abstraction." Miriam Hansen, Cinema and Experience: Siegfried Kracauer, Walter Benjamin, and Theodor W. Adorno (Berkeley: University of California Press, 2011), p. 5.

7. It is worth recalling, moreover, that all three authors wrote literary criticism as well, and that Balázs had been the head of the literary department of the governing council in Béla Kun's short-lived Soviet Republic in Hungary in 1919. Cf. Loewy, Béla Balázs.

8. Of course, this includes attention to other media. Drawing on Arnheim's numerous writings on the subject of television from 1930 onwards, Doron Galili has persuasively argued that even "this key thinker, who is best known for his commitment to concepts of medium specificity and interest in aspects that distinguish media from one another, was also attentive to questions of intermedial relationships." Doron Galili, "Television from Afar: Arnheim's Understanding of Media," in Arnheim for Film and Media Studies, p. 196. 
cially America's much-admired slapstick find their ways into the thematic and formal construction of these novels. Similarly, one might consider how "filmic writing" suffuses a novel like Ginster just as much as it does texts by other writers of the time, from Alfred Döblin to Irmgard Keun, from Anna Seghers to Dos Passos. Conversely, the literary output of Balázs, Arnheim, and Kracauer certainly invites us to reconsider the narrative and stylistic construction of their more properly theoretical texts; though my focus in the present essay lies elsewhere, I do mean my title to imply what I regard as the centrality of figurative, rhetorical, and other literary devices in the formulation of classical film theory. There is still much to be learned about the latter by analyzing, say, the "literariness" of Kracauer's film reviews from the 1920s or the hyperbole of Balázs paean to the new medium, its rhetorical construction of his own readership as a collective blessed with new powers of vision. ${ }^{9}$

But what emerges even more importantly from a reading of these novels and fairy tales are their properly film-theoretical dimensions. In keeping with Miriam Hansen's reminder, apropos of Kracauer, that "it would be shortsighted to restrict an account of [his] early film theory to writings that explicitly and exclusively deal with film,"10 I turn to these literary writings for the contribution they make to our understanding of Kracauer's, Balázs's, and Arnheim's canonical works on film. By reading the fictional prose alongside cinema and its theorization, then, I propose neither to retrace the "debates on cinema" among the literati of the $1920 \mathrm{~s}^{11}$ nor to revisit the place of cinema and literature in the "discourse networks" of the time, ${ }^{12}$ let alone to offer yet another elaboration of the overworked concept of "adaptation." If anything, I wish to reverse the thrust of the latter and investigate the construction of the novel in the spirit of classical film theory. My goal, then, is not to analyze these texts as exemplars of "filmic writing" in the age of silent cin-

9. On the literary qualities of Kracauer's early criticism, see Inka Mülder, Siegfried Kracauer, Grenzgänger zwischen Theorie und Literatur: Seine frühen Schriften 1903-1933 (Stuttgart: Metzler, 1985); on Balázs and spectatorship, see Sabine Hake, "Film, Folk, Class: Béla Balázs on Spectatorship," in FilmKino-Zuschauer: Filmrezeption/Film_Cinema_Spectator: Film Reception, ed. Irmbert Schenk, Margrit Tröhler, and Yvonne Zimmerman (Marburg: Schüren, 2010), pp. 159-71.

10. Miriam Hansen, Cinema and Experience, p. 3. Though the literary production of these three authors has until now not been considered jointly, and while Arnheim's novel has gone essentially unnoticed to date, I am not the first to draw attention to the give-and-take between Balázs's and Kracauer's literary texts and their elaborations on film. On Balázs, see in particular Hanno Loewy, "Space, Time, and 'Rites de Passage': Béla Balázs's Paths to Film," October 115 (Winter 2006), pp. 61-76, as well as Loewy's biography, Béla Balázs: Märchen, Ritual und Film (Berlin: Vorwerk 8, 2003); and Erica Carter, "Introduction," in Béla Balázs, Early Film Theory, pp. xv-xlvi. On Kracauer, see Mülder-Bach, Siegfried Kracauer, Christian Rogowski, "Written By Himself': Siegfried Kracauer's Auto-Biographical Novels," in Culture in the Anteroom, pp. 199-212; Jörg Lau, "Ginsterismus.' Komik und Ichlosigkeit. Über filmische Komik in Siegfried Kracauers erstem Roman Ginster," in Siegfried Kracauer: Zum Werk des Romanciers, Feuilletonisten, Architekten, Filmwissenschaftlers und Soziologen, ed. Andreas Volk (Zürich: Seismo, 1996), pp. 13-42.

11. See, for instance, the texts assembled in Anton Kaes, Kino-Debatte. Texte zum Verhältnis von Literatur und Film 1909-1929 (Munich: dtv, 1978).

12. See, most recently, Stefanie Harris, Mediating Modernity: German Literature and the "New" Media, 1895-1930 (University Park: Penn State University Press, 2009), as well as Francesco Casetti, "Adaptations and Mis-adaptations: Film, Literature, and Social Discourses," in A Companion to Literature and Film, ed. Robert Stam and Alessandra Raengo (Oxford: Blackwell, 2005), pp. 81-91. 
ema (the way Eisenstein, for example, reads Dickens) ${ }^{13}$ but to trace in them some of the central film-theoretical motifs elaborated by these and other authors at the time-among them the emphasis on perception and spectatorship, cinematography and montage, and the increasing visuality of culture.

Underpinning these motifs, I will suggest, is a common assessment of cinema as a quintessentially modern medium that registers and contributes to shifting constructions of subjectivity. The literary texts under consideration flesh out the contours of such a modern subject, and we might profitably read this as a contribution to film theory. But these texts also yield a further perspective on the theories with which they are indissolubly linked. Far from merely illustrating their authors' theoretical preoccupations in another mode or medium, they draw attention to a fundamental fact all too often overlooked in the discussion of film theory and its histories: the degree to which the elaboration of the "classical" theories of film was a project forged in exile and colored by the theorists' exilic experiences. Buried in books such as Visible Man, The Spirit of Film, Theory of Film, and the editorial history Film as Art, ${ }^{14}$ the dimension of exile becomes explicit in texts such as The Coat of Dreams and Eine verkehrte Welt and is present metaphorically in Ginster. These authors' literary imaginations, I hope to show, circle around questions of exile and attendant fantasies if not of repatriation then of reparation or repair-fantasies, I will argue, that inform their theoretical projects at some fundamental level as well.

To recover this dimension, we need only recall the circumstances under which our three authors composed their literary works. When the young Balázs accepted Schwarzwald's commission for Der Mantel der Träume in Vienna, he had only recently parted ways with his erstwhile friend and collaborator György Lukács and fled the failed Hungarian revolution; what followed was a long period of exile in Berlin (where he wrote his two major volumes on film) and the Soviet Union. The title tale of Balázs's collection, to which I turn in detail below, provides only one instance among several in which forms of exile enter into fairy-tale plots. ${ }^{15}$ Arnheim's novel was similarly written in forced exile in Italy and the U.K., and it is here that the motif of exile as the novel's "topsyturvy world" becomes most explicit: from the moment he crosses a border by train in the opening scene, the protagonist is utterly displaced-and although

13. Cf. Sergei Eisenstein, "Dickens, Griffith, and the Film Today," in Film Form: Essays in Film Theory, ed. and trans. Jay Leyda (New York: Harcourt, 1949), pp. 195-256.

14. Film als Kunst (Berlin: Rowohlt) was published in 1932 one year before Arnheim's forced flight into exile; it would be wrong, therefore, to claim that the book is tinged with any history of exile. The volume's widespread influence, however, can arguably be traced more to the abridged English edition of 1955 than to the German original. On the degree to which the truncated Film as Art represents not only a shortened but an abstracted, hyper-formalist version of an argument whose roots in daily, lived, and social experience have been severed in translation, see Eric Rentschler, "Rudolf Arnheim's Early Passage."

15. Other fairy tales that spin out the motifs of exile, longing, and displacement include "Die Sonnenschirme," about a couple's attempt to find peace under magical parasols that all seem to conspire against a stable sense of home, and "Die Freunde," in which the prolonged separation of two friends results in a rupture that can only be mended in the afterlife. 
the novel never explicitly discounts the possibility that he may be traveling as a tourist, it seems equally significant that the possibility of a return home is never broached. Finally, Kracauer would be forced to emigrate, like Arnheim, by the Nazi's seizure of power and would write his second novel, Georg, during his French exile. To be sure, he completed Ginster while still in Germany, where he was working at the hub of cultural life at the Frankfurter Zeitung. But, as numerous commentators have noted, the motif of homelessness-or, as Kracauer himself would put it, extraterritoriality-predates the forced departure from his home country. ${ }^{16}$ It is significant that in the original version of the novel, the semi-autobiographical figure of Ginster, who, as we shall see, never fits in and always wants to "trickle away," ends up stranded in Marseille. Kracauer would go on to reflect explicitly on this tangential, exilic disposition, raising it to a privileged epistemological vantage point in his final work on historiography. ${ }^{17}$

Homelessness, then, was to these authors both a transcendental notion and a lived reality that profoundly marked their writings. While this positioning is less apparent, at first glance, in the film theory for which they became known, I propose that we conceive of their less frequently read literary prose as, among other things, middle texts between authorial biography and cinema theory-fiction that mediates between lived experience (of exile, of cinema) and the attempt to provide a generalizing, theoretical account of that experience. A reading of these film theorists' novels, with their displaced characters who express homesickness and longing, however romantically inflected, in disturbingly upside-down worlds, should prompt us to reread the seminal texts of classical film theory for how they position the new medium and how much of classical film theory is informed by, and produced from, exilic experience.

16. "Kracauer's exile did not begin in 1933, and his later plea for a personal 'extraterritoriality' merely made explicit a persistent motif in his writings from the beginning." Miriam Hansen, Cinema and Experience, p. 286 n. 24. Reading an important essay published soon after Kracauer's arrival in New York, Inka Mülder-Bach similarly argues that this arrival "marks a position that Kracauer had outlined since the 1920s and which informs his early writing both as a concept and a textual perspective." "The Exile of Modernity: Siegfried Kracauer's Figurations of the Stranger," in Culture in the Anteroom, p. 280. Kracauer himself confessed to "a long-held, deep-seated need to live exterritorially" in a 1963 letter to Theodor Adorno, and he organized parts of his correspondence with the latter in a folder labeled "Exterritorialität." See Theodor W. Adorno and Siegfried Kracauer, Der Riß der Welt geht auch durch mich: Briefwechsel 1923-1966, ed. Wolfgang Schopf (Frankfurt: Suhrkamp, 2008), p. 621. For further elaborations of the motif of extraterritoriality in Kracauer, see, among others, Martin Jay, "The Extraterritorial Life of Siegfried Kracauer," in Permanent Exiles (New York: Columbia University Press, 1986), pp. 152-97; Enzo Traverso, Siegfried Kracauer: Itineraire d'un intellectual nomade (Paris: Editions La Découverte, 1994).

17. Kracauer's History works through several figures of the historian, among them Ahasverus, the Wandering Jew; Orpheus; and the Exile. These figurations serve to shore up Kracauer's overall claim that historical knowledge is best constructed in "the near-vacuum of extra-territoriality": only in a "state of self-effacement, or homelessness," Kracauer asserts, can the scholar fully grasp the object of study. Kracauer, History: The Last Things Before the Last (Oxford: Oxford University Press, 1969), p. 84. 


\section{Dreams, Inversions, Disappearing Tricks: Fables of Extraterritoriality}

The image that inspires the title of Balázs's book and its eponymous fairy tale is an ornate rendering of a royal couple. The watercolor is dominated by the king, who covers the center and foreground of the image to the point of dwarfing not only the houses and spires in the (presumably distant) background, but also the queen just behind him. And yet, questions of perspective and relative size recede in importance in relation to the watercolor's emphasis on surface and ornament: here, too, the king takes center stage with his elaborately designed cloak-but rather than standing out in front of the background, he becomes part of a planar composition; the contour line hardly contains his massive body, which seems to blend with the similar colors and ornamental echoes of the buildings in the background.

Little wonder, then, that Balázs seized on the motif of the cloak as a surface, a canvas on which the empress stitches the images of her dreams. The accompanying "Oriental" fairy tale, "Der Mantel der Träume," tells the story of Emperor Ming-Huang and his wife, Nai-Fe.18 Their love, we learn, is "damaged" because Nai-Fe, who died too early in a previous life, has a "dreaming soul": even when the emperor holds her in his arms, her soul drifts away in reverie. One night, she divines the solution to this problem of too distant (or too distracted) love: in her sleep, she sees her husband

wearing a marvelous cloak on which all the images of her dreams had been embroidered.... His cloak carried the entire dreamland for which her soul yearned. Nai-Fe's heart was delighted and filled with happiness, for now she could keep her gaze upon the emperor and hold it forever. No longer did she have to choose between the path of her dreams and the path of her love. 19

As in many other fairy tales by Balázs, the emperor and his wife long for a utopian form of love or friendship that overcomes the separation of self and other, a complete-if mystical-union. ${ }^{20}$ As Hanno Loewy notes, Balázs translated his own sense of alienation into a "tireless search for a medium that would create unities between artist and reader, desire and form, object and subject, a search that led him to wallow in romantic irrationalism and to experiment with the widest variety of mediums and genres"-a search that during Balázs's early years would lead him to cultivate the fairy tale in particular as a medium of mystic union. ${ }^{21}$ What sets

18. On the pervasiveness of Orientalism at the time when Balázs was writing, see the review of the recent English translation of Der Mantel der Träume by Eliot Weinberger, "The Man Who Wrote Everything," New York Review of Books, Nov. 25, 2010, pp. 52-53.

19. Béla Balázs, The Cloak of Dreams, p. 66.

20. See especially the tales "Die Opium-Raucher" and "Die Freunde" in Der Mantel der Träume.

21. Hanno Loewy, "Space, Time." As Zipes puts it, Balázs used the fairy tale "as a genre to pursue his mystical notion of identity and to celebrate his oneness with the world in opposition to the forces of alienation." Jack Zipes, "Béla Balázs, the Homeless Wanderer, or, The Man Who Sought to Become One with the World," in Balázs, The Cloak of Dreams, p. 11. 


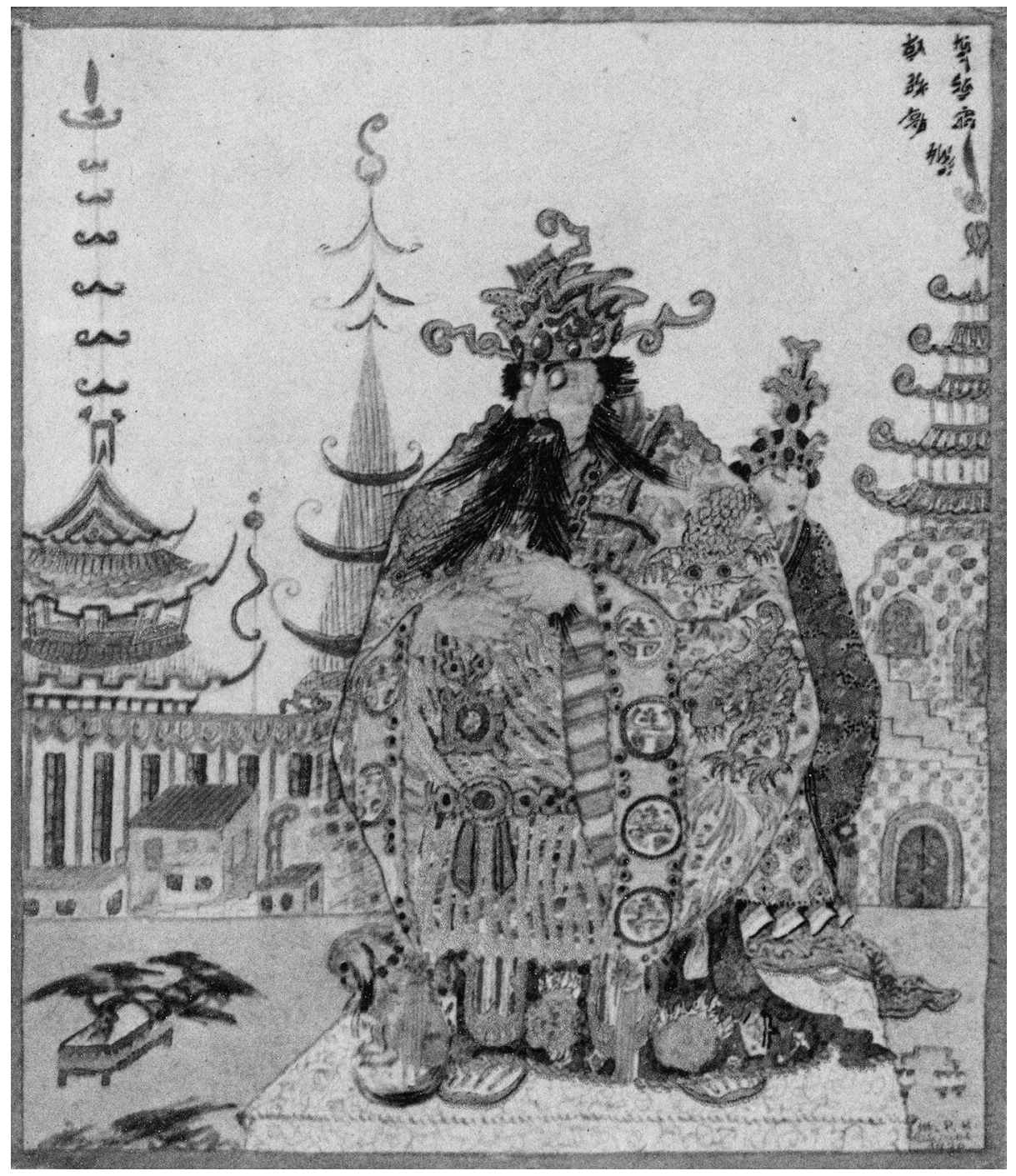

Watercolor from Der Mantel der Träume: Chinesische Novellen von Béla Balázs mit 20 Bildern von Mariette Lydis. 1922. 
the title tale apart from Balázs's other stories for our purposes is the central device of the cloak as a material-if magical-support for that oneness or union. Having spent five years embroidering it with her innermost images, Nai-Fe brings the coat to the emperor and is "filled with joy and happiness" at the sight of her husband "wrapped in her dreams" (in ihre Träume gehüllt, 68). The cloak, we might say, functions as a screen on which Nai-Fe both projects and beholds her dream images. In other words, it is a visual medium that promises immediacy and the fusion of the spectator with the image-a dispositif that will resonate strongly in the history of film theory, where we find critics such as Jean Baudry and Christian Metz developing notions of the screen, the spectator, and the fusion of perception and representation along similar lines. 22

In the tale of Ming-Huang and Nai-Fe, this projection comes at a price. As the lovers realize once the emperor tries on the magical cloak, its dream images create a distance that cannot be bridged physically: when Nai-Fe attempts to approach her husband, "the entire, spacious dreamland lay between her and the emperor, and she couldn't come to him" (68). Again, the two are confronted with a stark choice between empty, physical proximity and fulfilled, dreamy distance. Nai-Fe tells the emperor,

If you take off the cloak, you can hold me in your arms, but my soul will be far away from you. If you wear the cloak, I won't be able to approach you, and I won't be able to come to you. But the longing of my soul will eternally cast its glances upon you (69).

Forsaking physical presence, the emperor chooses the cloak-which is to say: an image-based medium of the soul. In this, as other commentators have also observed, the fairy-tale character anticipates rather strikingly the contemporaneous turn of its author, Béla Balázs, from literature to film, as well as his theorization of the cinema as a new folk art and the medium of the soul..23 Balázs's subsequent book, Der sichtbare Mensch (Visible man), of 1924, is suffused with the same Romantic motifs that he was working out in fairy-tale form in 1921-motifs that include the expressivity of a visual medium and its constitutive link to what Balázs (like the early Lukács) calls the "soul"; the fusion of self and other in the act of spectatorship; and the medium's power to convey the "physiognomy" of things. Like the cloak of dreams, cinema is for Balázs a medium that lends expression to the soul, "the visual corollary of human souls immediately made flesh." 4 What materializes on the coat as "all the images of [Nai-Fe's] dreams" is precisely

22. See Christian Metz, The Imaginary Signifier: Psychoanalysis and the Cinema (Bloomington: Indiana University Press, 1986); Jean-Louis Baudry, "The Apparatus: Metapsychological Approaches to the Impression of Reality in the Cinema," in Film Theory and Criticism: Introductory Readings, ed. Leo Braudy and Marshall Cohen (Oxford: Oxford University Press, 1998), pp. 760-77.

23. Loewy suggests that "The Cloak of Dreams" reads "like a poetic illustration of Balázs' theory of the cinema." Loewy, "Space, Time," p. 66. See also Loewy, Béla Balázs, and Hake, "Film, Folk, Class."

24. Balázs, Early Film Theory, p. 11. 
what Balázs will later theorize as the expressive movement of the soul, the Ausdrucksbewegung (expressive movement) as it becomes manifest on the cinema screen through devices such as the close-up. ${ }^{25}$ As if echoing the constellation of his earlier fairy tale, Balázs now defines the close-up in cinema, "film's true terrain," as a naturalist device but imbues it with a tenderness that prompts him to speak of a "naturalism of love." 26 At the same time, he places the medium of cinema under the aegis of expressionism for its revelationist physiognomies, its ostensibly unique ability to "represent [the] 'face of things." 27 Zeroing in on the links between expressionism, dream, and vision that would have been apparent to anyone writing on film in the early 1920s, he reprises the direct address with which Der sichtbare Mensch occasionally interpellates its readers; but he also reprises the central motif of "The Cloak of Dreams," in which a landscape, embroidered on a screen-like cloak, is but an extension of Nai-Fe's soul-her physiognomy, as Balázs would call it:

Have you never had this curious dream experience? You are out walking in a landscape and recognize in it the face of one of your friends or enemies. It is nothing more or less than a landscape. But it contains an obvious physiognomy that betrays it... The capacity to illuminate the secret affinity between the dreamer's physiognomy and that of his dream is one of the most wonderful miracles of film art.28

If "The Cloak of Dreams" is indeed an allegory of cinema, as Sabine Hake has suggested,29 then what it allegorizes is not simply the historical rise of the medium or its shifting styles but also the "spirit of film" as theorized by Balázs himself_-its physiognomic qualities as a new folk art and heir apparent to the oral tradition of the fairy tale.

"All of his life," writes Loewy, Balázs “wished to remain a writer. He never got over the fact that his writing was lost in the shadow-or better the light—of film."30 Perhaps, by reading his film theory as a continuation of his fictional work, we might rehabilitate the latter-both for its intrinsic merits, which have recently been recognized by a new German edition and a translation into English, and as a contribution to a history of classical film theory. To be sure, the cinema produces fairy tales or fantastic genres, films that offer visual equivalents for Balázs's literary themes of mystical

25. As a "revelationist" medium (Turvey), cinema has the power to visualize-and hence make accessible-the physiognomy of the soul in its outward appearance, its Ausdrucksbewegung. On the notion of Ausdrucksbewegung and its continued relevance for film theory in its Deleuzian derivations, see Hermann Kappelhoff, Matrix der Gefühle: Das Kino, das Melodrama und das Theater der Empfindsamkeit (Berlin: Vorwerk 8, 2004).

26. Balázs, Early Film Theory, p. 39. On the relation between fairy tale and close-up, see Erica Carter's excellent discussion, where she shows that "the fairy-tale prefigures . . . many features of the close-up's organization of time.” Carter, "Introduction,” pp. xxviii-xxxii.

27. Balázs, Early Film Theory, p. 46.

28. Balázs, Early Film Theory, p. 49.

29. Hake, p. 168.

30. Loewy, "Space, Time," p. 61. 
union, utopian love, and inner visions of the soul-after all, these are hallmarks of the expressionist cinema that was flourishing at precisely the moment of Balázs's turn to cinema. But my point here is that the fairy tale reads not like the blueprint for a film script but as an elaboration of film theory in a fictional mode. By the same token, Balázs's film theory continues to elaborate the insights he gathers from his preoccupation with fairy tales. For all its insistence on medium specificity, ${ }^{31}$ Der sichtbare Mensch becomes legible as a trans-medial aesthetics of expressivity that subsumes fairy tales and the cinema as two equally valid avenues for the manifestation of the soul. If anything, the literary texts make more explicit the motif of longing that underpins so much of Balázs's writing, whether in literature or on film: a Romantic motif that the fairy tales render legible as a response to alienation and displacement. The fantasy that animates these tales, in other words, is that of a magical/utopian world in which identification and desire are mutually enabling and where the latter's realization does not exact the price of separation, as in the unbridgeable distance that keeps Nai-Fe and the emperor apart. It is the fantasy of a "society of love," as the young Lukács still called it, a fantasy tested and debated in the famous "Sunday Circle" that both Lukács and Balázs frequented during their Budapest years. Without denying the Central European, cosmopolitan dimensions of this fantasy, which Erica Carter has pointed out, it is perhaps worth recalling that The Cloak of Dreams formulates the tale at a remove from the Sunday Circle and the memories of Budapest, placing it at the beginning of an exilic trajectory that will wind up, somewhat bitterly, in Moscow.

Even more explicitly than Balázs's fairy tales, Rudolf Arnheim's Eine verkehrte Welt functions on the level of fantasy, as is evident from its generic inscription as a phantastischer Roman. But the latter operates on a completely different aesthetic principle: where Balázs yearns for a re-enchanted world in which meaning and expression and dream world and material world (or what Lukács called "the soul and the forms") are coextensive, Arnheim concocts a strict logical inversion of our world, where binary distinctions are not suspended but verkehrt, or turned upside down, as the title readily suggests. So clear is this procedure, in fact, that it also indexes the underlying wish for a situation in which such inversions might be righted again and the displaced subject of the novel regain his bearings.

The story begins as the nameless first-person narrator is crossing a border by train. He carries with him a notebook for the purpose of "writing down what I experience in your country," as he tells the customs officer (8). The experiences that he proceeds to relate over the course of the novel map out a strange world indeed: its

31. Balázs speaks of the Wesensverschiedenheit (essential difference) between film and literature (Balázs, Early Film Theory, p. 23), and from a comparison between different forms of expressive movement, for example, he concludes that "the screenplay ... must never be the product of the literary imagination" (ibid., p. 26). 
inhabitants sleep during the daytime and go about their business at night; instead of wearing clothes, they hide only their naked faces behind masks. Food, a privilege of the working poor, is distributed as a form of entertainment rather than responding to a basic biological need; dirt is a virtue, and cleanliness shameful. In this country, clocks run according to the whim of their owners rather than following a pre-given rhythm of seconds, minutes, and hours; public transportation is designed to run slowly, unreliably, and with as many accidents as possible rather than serving the needs of travelers. Social hierarchies, too, are reversed: women rule, children command adults, work is a privilege reserved for the upper classes, and the poor lord it over the downtrodden rich who occasionally take to the streets for their rights (as described in a chapter entitled Reichendemonstration, or "march of the rich"). Several chapters detail the working of such public institutions as schools, the newspaper, and the decidedly Kafkaesque "patience office" (Geduldamt) — a blend of police station and hospital which you enter healthy and leave sick. One chapter, finally, is devoted to a strange blend of cinema and television called Erziehungskino (education cinema): here, the audience assembles to watch moving images projected on a screen, but these turn out to be live transmissions. In an inversion of television broadcasting, the images here are somehow transmitted not to the home but from cameras hidden in a regular family's apartment. Where the narrator expects to see a fictional film, he is confronted with filmed reality. Nonetheless, he is impressed by the powerful performances of the family members-even after he has been told that they are not actors. His companion, the mask-maker's daughter, explains the aesthetic effect of second-order reality: "It's in our nature that we only have eyes to see what every day brings when things are represented to us in images and we contemplate them from our seats" (144).

Of course, this moment of aesthetic contemplation and revelationist vision in the Erziehungskino is also a mise-en-abyme, a moment in which the novel mirrors itself in the object it represents: like the strange events that unfold in the movie theater, the plot of Eine verkehrte Welt is designed to "open our eyes" to the construction of everyday reality; the upside-down world allegorizes our ostensibly right-side-up existence, and the narrator functions as an ethnographer whose gaze at the foreign environment has the power of estranging our own notions of self and society. The result is profoundly unsettling-for the reader as well as the narrator, who wonders whether he is gradually becoming used to the absurdities of his new world and no longer perceives them as such, or whether he is now seeing himself for who he really is. "With increasing frequency," he notes, "I appeared strange to myself, foreign, laughable, even inappropriate in one thing or another" (111).

It is no coincidence that the cinema (coupled with the nascent technology of television $)^{32}$ plays a central role in this alienation effect, not because of the par-

32. Arnheim was intensely aware of the changing audiovisual landscape during the 1930s, when cinema and radio had to compete, or find a way to coexist, with broadcast television. As early as 1930, he was anticipating, "within measurable time," the advent of "films . . broadcast from a central projecting station by wireless" and available in the private home. Rudolf Arnheim, Film (London: Farber and Farber, 1933), p. 294; quoted in Galili, "Television from Afar," p. 197. 
ticular contents of the stories it tells-be it the science fiction of Eine verkehrte Welt or the live reality of the Erziehungskino-but because of the distance it places between reality and representation and the aesthetic effect that results. After all, this is how Arnheim himself had theorized "film as art" a few years prior to leaving Germany and embarking on what would remain his only attempt at fiction. As is well known, the premise of Film als Kunst (Film as art), from 1932, was that, like other media, film could but did not necessarily have to be used to create art. To argue the artistic value of film, then, Arnheim proceeded to outline a series of fundamental distinctions between what he called Weltbild, the image of the world, and Filmbild, the image of silent cinema. ${ }^{33}$ The latter is determined by various factors: framed film images do not allow for peripheral vision and translate the colors of the world into a gray scale; stereoscopic vision is replaced by the monocular perspective of the camera, reducing the possibilities for depth perception; and for the spectator fixed in his/her seat, the senses of cinema-sight and sound-are isolated from the other senses, which offer no input to accompany the visual perception of, say, a roller coaster amplified by a drum roll from the orchestra pit. Film, according to Arnheim, is art to the degree that it emphasizes these distinctions and uses them as aesthetic devices.

None of this will be news to the reader of classical film theory. What appears significant in connection with Arnheim's novel, however, is the consistency of the underlying impulse to explore the world aesthetically through an epistemology of inversion forged in exile: cinema, following Arnheim's theory, constructs an image of the world according to laws of opposition and difference every bit as strict as those that govern Eine verkehrte Welt. Arnheim describes these laws in an introductory note to the novel's manuscript, which describes the literary process as a mechanical application:

$[F]$ or certain malicious reasons the author has thought it worth while to describe an imaginative world in which peoples' manners, public institutions, private and social life are just the contrary of what they are supposed to be in our own world. By transforming, in a more or less mechanical and theoretical way, black into white, up into down, plus into minus, and so on he came to a number of propositions which seemed to possess a strange vital energy. 34

In other words, and in keeping with an underlying impulse of science fiction as a genre, ${ }^{35}$ the emphasis here is both on the aesthetic surplus value and on the knowl-

33. Arnheim, Film als Kunst, p. 24.

34. Arnheim papers, Deutsches Literaturarchiv, Marbach.

35. Elmer Rice's amusing novel A Voyage to Purilla (New York: Cosmopolitan, 1930) provides a kindred contemporary use of science fiction to probe aspects of cinema: two explorers leave Earth to find a planet governed by the laws of cinema, replete with voice-of-God narration and extra-diegetic music. The effect, of course, is to estrange and reveal the formal conventions that classical Hollywood cinema is at pains to hide in plain sight. Thanks to Dana Polan for this reference. 
edge produced by turning things on their head. The "formula of inversion," as Arnheim calls it, "proved to be a spell able to conjure up odd dreams which look like telling some queer sort of truth-as dreams often do-and in which the author felt tempted to indulge. Thus, after having applied the key to the entrance, he confined himself to describe what he saw and heard." If the novel draws this queer sort of truth-that is, its aesthetic value-from the inverse relationship of the narrator's home country and the strange customs abroad, then cinema draws its aesthetic qualities from the distinctions between the spectator's ingrained habits of perception and their modification by the cinematic apparatus, between Weltbild and Filmbild. ${ }^{36}$

This, in any event, is the version of Arnheim's film theory handed down from the 1955 edition of Film as Art-a book that differs in profound ways from Film als Kunst as originally published in 1932. As Eric Rentschler has detailed in a careful rereading of the German original, the earlier version was considerably less invested in the strict distinction between Weltbild and Filmbild, or between "world" and "art." This allowed for more excursions into the realm of the social than the 1955 version, which seems peculiarly cleaned up in this regard. 37 We can only speculate on the reasons for this reduction or, as Rentschler puts it, "repression." Rentschler himself wonders, with some justification, whether the pressures of the McCarthy era on a Jewish emigrant from Germany with a leftist past might have had something to do with it. For the structural isomorphism between the sciencefictional conceit and the world/art distinction in Film as Art is one that the novel urges us to link to the experience of exile itself. The difference between Arnheim's novel and his aesthetic theory, then, would appear to lie in the valence of (il)legibility: whereas in Eine verkehrte Welt the exiled protagonist is dumbfounded, and semiosis fails as he is confronted with signs he does not know how to read, the aesthetic argument of Film as Art holds, by contrast, that the very illegibility of the film image as image of the world-its difference from the routine, mechanical reproduction of the world around us-is what grounds the semiotic power of cinema. The emphasis on this difference, this illegibility, is exacerbated under conditions of exile: this is the lesson of the novel-the structuring fantasy of which is that of legibility restored-as much as of the 1955 edition of Film as Art, where we find this fantasy sublimated in an aesthetic argument in favor of formal estrangement. It is a lesson that Arnheim will underscore further in his 1963 review of Kracauer's Theory of Film, to which I will return in conclusion.

Critics have tended to place Arnheim's "formalist" approach-his insistence on the power of aesthetic form, be it literary or cinematic, to estrange our perceptual

36. "Die Möglichkeit, daß mit der Filmkamera Kunst gemacht werden kann, ist also jenen ... Unterschieden zwischen Filmbild und Wirklichkeit zu danken" (we consequently owe the possibility of making art with the film camera to those distinctions between the film image and reality), Film als Kunst, p. 49.

37. Rentschler, "Rudolf Arnheim's Early Passage." 
habits-in opposition to Siegfried Kracauer's "realism" and its ontological assumptions. But if we turn from Kracauer's summa, Theory of Film (1960), to the lesser-known (but equally momentous) Ginster, we find in the latter a commitment to modernist devices on par with Arnheim's notions of aesthetic form. 38 A look at Kracauer's novel, then-which Theodor Adorno, for one, considered "Kracauer's most significant achievement" 39 _ will serve to relativize Kracauer's realism and highlight its formal contours in the realms of both literature and cinema. Beneath the "redemption" that film is capable of offering reality, and contrary to Kracauer's insistence that his "material aesthetics" stand in opposition to previous formal approaches, ${ }^{40}$ we can detect a profound commitment to aesthetic construction in his work. As will become apparent to the reader of Ginster, that aesthetic construction centers on a dialectical understanding of reification as both an alienating force to be overcome and as a productive, unsettling cognitive effect, achieved through the modernist device of estrangement, or what the Russian Formalists called ostranenie. 41

Kracauer's approach differs, to be sure, from that adopted in Eine verkehrte Welt. Where the latter estranges us from our ingrained "world picture" through inversion, Ginster performs this estrangement through an ingenious deployment of narrative voice and an attendant unsettling of both the subjectivity and objectivity of characters. The quasi-autobiographical plot follows a hapless protagonist from the outbreak of war in 1914 through the end of World War I. ${ }^{42}$ From his student days in Munich, he stumbles through a thankless job as an architect in Frankfurt, into the military (where he mainly "peels potatoes against the enemy," 204), and out again. He ends up in the provinces, where he waits out the conclusion of the war in a corrupt municipal office, drafting architectural plans and an accompanying book publication. ${ }^{43}$ Told in the third person, the narration is col-

38. Miriam Hansen astutely points out the anti-naturalist proclivities of Kracauer's early film criticism as well: "To achieve its very specificity," Kracauer notes in a 1923 review, film "has to completely break apart the natural contexts of our lives." See Hansen, Cinema and Experience, p. 12.

39. Theodor W. Adorno, "The Curious Realist," in New German Critique (Fall 1991), p. 171. Adorno already notes how the novel "sends roots deep into modernism" (p. 169), and Gertrud Koch likewise speaks of a "thoroughly modern novel," seeing in Ginster "a Kafkaesque younger brother of Musil's "man without qualities.'” Gertrud Koch, Siegfried Kracauer: An Introduction, trans. Jeremy Gaines (Princeton: Princeton University Press, 2000), p. 53.

40. See Theory of Film, p. xlix.

41. Significantly, this approach also informs Kracauer's turn to sociology in The Salaried Masses, which adopts the notion of the "mosaic" to define its impressionistic approach to social reality in view of the fact that this reality is itself "a construction," as Kracauer famously observes. If Theory of Film approaches this idea of reality as a construction obliquely, from the side of the aesthetic, The Salaried Masses takes aim at it squarely, from the side of the social.

42. A final chapter, omitted in later editions of the novel, takes place in Marseille five years after the war. All references to Ginster follow the complete text reprinted in Siegfried Kracauer, Werke, vol. 7: Romane und Erzählungen (Novels and stories), ed. Inka Mülder-Bach with Sabine Biebl (Frankfurt: Suhrkamp, 2004).

43. On the motif of stumbling-stolpern — in the novel and its relation to Charlie Chaplin's gags, see Lau, "'Ginsterismus." 
ored strongly by the protagonist's moods, with his inner thoughts frequently related as quasi-objective narration in free indirect discourse. This narrative device, which blurs the boundaries between subjective and objective voice, effectively enacts, at the level of aesthetic form, the quasi-anonymity that is both announced and retracted by the book's title, Ginster: Von ihm selbst geschrieben (Ginster: Written by himself). Objectified through a name that is not the (anonymous) author's-nor even really that of the protagonist (who, as we learn in the first paragraph, "wasn't really called Ginster"44) — the main character is nonetheless both writer and subject of the novel in which he appears in the third person. .

Like Kracauer, moreover, our nameless hero has earned a Ph.D. but is planning to live without this title, "incognito, so to speak" (11). From here, the novel will proceed to elaborate what it might mean for its protagonist to remain unknown. On some level, this might be construed as simply wanting to blend in, if not as the kind of "deliberate head-in-the-sand policy" that Adorno ascribed to Kracauer himself in an underhanded tribute on his mentor's 75th birthday. ${ }^{45}$ But there is more to this "incognito." As a fictional protagonist, Ginster makes for a curiously reticent subject-one who says of himself that "after all, he was nothing" (145), who "would have preferred not to become anything," (24) and who repeatedly dreams of somehow vanishing from the scene altogether. In a conversation with an older woman whom he admires, for example, Ginster blurts out, in spite of himself ("aus einem ihm unerklärlichen Sprechzwang" [due to a compulsion to talk, for which he had no explanation]), the difference that sets him apart: other people, he notes, "are interested in their lives, they have goals, want to own and achieve something. Every person I know is a fortress.” (132) If this sounds, among other things, like a workable description of fictional protagonists-well-defined characters with clearly articulated desires to motivate their actions-Ginster, by contrast, is an antihero at best: "For my part, I want nothing. You probably can't understand this, but I'd rather trickle away." 46 Kracauer finds several formulations for his protagonist's impulse to vanish: on a purely physical level, he tries to avoid

44. "Eigentlich hieß er gar nicht Ginster, der Name war ihm aus der Schule geblieben.” Ginster, p. 23. The subject of Ginster's name comes up repeatedly in the novel. In addition to the prominent discussion of Ginster as, literally, a misnomer, in the first paragraph, see the fascinating scene of Ginster's first roll call at the military. As he is waiting for his name to be called, he becomes distracted by the responses ("HereHere-Here") of the other soldiers. As a result, the "string of syllables" constituted by the jumble of names comes to a halt: "Suddenly torn right in half, the Heres also ceased. A void, and in this void a single name, alone. The name seemed foreign to Ginster, but it did awaken in him some memory; as if he had encountered this name repeatedly in the past. It took quite a while until he grasped that it was his own. Helplessly, he stared at the name that occupied the entire courtyard and made demands that he, Ginster, could not possibly meet, for after all, he was nothing and could not make any claims to being named individually with such power in the courtyard. He hesitated for a long time whether he should not rather repudiate himself. In the end, it occurred to him that he belonged externally to the name and might commit a legal infraction by withdrawing from it" (p. 145).

45. Adorno, "The Curious Realist," p. 172.

46. "Die Menschen sind an ihrem Leben interessiert, sie haben Ziele für sich, wollen besitzen und etwas erreichen. Jeder Mensch, den ich kenne, ist eine Festung. Ich selbst will nichts. Sie werden mich nicht verstehen, aber am liebsten zerrieselte ich." Ginster, p. 132. 
the draft by eating less and losing weight, but Ginster's maxim to "hunger himself away, just away" (181) betrays broader metaphysical-or at least metafictionalimplications; as does his desire to flee into a place beyond space ("gerne wäre Ginster ins Raumlose geflüchtet”) (117), or to replace his bodily existence with a different aggregate state altogether: "for his part, [Ginster] ... would have liked to be gaseous [gasförmig]" (140). To put this in the cinematic terms that hover just below the surface of this text: Ginster dreams of the dissolve.

This evanescent subjectivity has its flip side in the obstinacy of objects and the objectification of human beings: where either the fictional subject dissolves along with the narrative categories of desire, motivation, and agency or the only remaining desire is one for dissolution into gaseous matter without any spatial extension, a reified world comes into view. As Gertrud Koch rightly observes, in Ginster "only the material world of objects offers hooks for the eyes and for language to find an anchor." 47

In a reversal characteristic of much of Kracauer's writing, though, the crucial object among objects turns out to be the human being-or rather the human body. Ginster himself is a case in point: during a dance lesson, a break from the spiritless instruction finds him "an orphaned instrument" ("ein verwaistes Zweckinstrument" [28], leaning against a wall that had previously permitted others to practice their steps. On a different day, after a morning at the office, he "gradually dissolved, his contours began to run, and he was gone, in the wallpaper"48: the motif of reification joins that of the vanishing subject. Faces and bodies become disfigured to the point that they transmute into objects: as a woman speaks, her face assumes "the animation of a beautiful grotto formation" (30); the narration turns people into their accoutrements when a "lorgnon fixates Ginster" (31) and mother and aunt recede from view as "two hats, two coats. First straight ahead and then right, down Main Street" (70).

The fragmentation and reification of individual human bodies is most noticeable in descriptions of the military. Arms and legs become autonomous objects, so many machine parts controlled by mechanical processes rather than individual subjectivity. When the arm of Ginster's friend Otto salutes passing officers, metonymically identified merely as uniforms, Ginster thinks to himself that the military has

forced him entirely into a rectangle ... an automaton. With every other uniform, the arm went up. It was not raised by Otto, but bolted up on its own accord. Otto would not have recognized the uniforms. The arm had to have been mounted with sprockets in his body. The system was operated remotely by the uniforms. It could not be switched off and presumably worked much better without Otto (50).

What happens to Otto's arms also transpires with Ginster's legs. Once in the mili-

47. Koch, Siegfried Kracauer, p. 37.

48. "Blieb er einen Vormittag im Büro, so zerfloß er allmählich, die Konturen lösten sich auf, weg war er, in den Tapeten." Ginster, p. 77. 
tary, he works at developing automated salutations similar to Otto's and participates in drills where the object is "to fling the legs in such a manner that they flew over the entire barrack yard. Not that this would even have been all that bad, quite the opposite. Ginster was pleased to be able to dismiss, if not himself, then a few extremities at least." 49 The drill, like a later march of the troops to the countryside, turns into an extended Ballet mécanique, its emphasis on autonomous legs a literary echo of the dancing mannequin parts in Léger's 1924 film.

In 1931, three years after the publication of Ginster, Kracauer would review the "failed experiment" that was Buster Keaton's first sound film, Free and Easy, contrasting it with the successful silent comedies. What had set the latter apart was their medium-specific triumph over (literary) language: there is "hardly a literary technique (Gestaltung)," Kracauer writes, "that could capture those modes of behavior that silent film had already discovered and represented completely." 50 But how are we to evaluate the apparent medium-specificity argument when Kracauer's own literary technique approximates that of silent cinema? In a review of 1926, Kracauer had described Chaplin's screen persona as "a lacuna" ("ein Loch"):

he has no will; in place of the drive to self-preservation and the hunger for power, he exhibits nothing but emptiness, as blank as Alaska's snow fields. Others have a consciousness of themselves and enter into human relationships; he has lost track of the Ego.... And since he owns no Ego: how could he defend it against the great Ego-bundles? He shrinks from a door if it opens behind him, for it, too, is an Ego; everything that takes command, things dead and alive, everything has power over him, before which one must draw one's little hat, and thus he always draws his hat.51

For contemporary readers, this description of Chaplin resonated with Kracauer's evocation of Ginster: dating back to Joseph Roth's glowing and influential review, Ginster's meanderings through the plot of the novel have been compared to Chaplin's stumbling characters in his films: "Ginster in war, that's Chaplin in the Department Store" was the tag line the publisher S. Fischer adopted from Roth to market the book. ${ }^{52}$ Whether they stumble through literary or cinematic plots, Ginster and Chaplin are both figures of alienation, medium-specificity notwith-

49. "Es galt, die Beine so aus dem Körper zu schleudern, daß sie über den ganzen Kasernenhof flogen. Das wäre nicht einmal schlimm gewesen, im Gegenteil, Ginster freute sich, wenn nicht sich selbst, so doch ein paar Gliedmaßen entlassen zu können." Ginster, p. 159.

50. Siegfried Kracauer, "Mischmasch," in Werke, vol. 6, book 2 (Frankfurt: Suhrkamp, 2004), p. 539. On the following argument regarding the links between Chaplin and Ginster, see also Lau, "'Ginsterismus."”

51. Siegfried Kracauer, "Chaplin," in Werke, vol. 6, book 1, pp.269-70.

52. Joseph Roth, "Wer ist Ginster?," in Frankfurter Zeitung, Nov 25, 1928; Ernst Bloch had discovered the same resonance in a letter to Kracauer, who had sent him the first seven chapters while he was still completing the novel. Declaring Ginster to be a new type of hero in literature, he admits that "only from the cinema do certain traits translate, from Chaplin and Buster Keaton; instead of slamming doors, here it is battles or the drafts they produce at home." Quoted in Lau, "Ginsterismus," p. 15. 
standing. Kracauer's own literary technique, in other words, did "capture those modes of behavior that silent film had already discovered and represented completely," and his film criticism and theory from the 1920 s on valorized these modes as part of his cultural poetics. 53 For the film theorist Kracauer, the power of estrangement that had animated the author of Ginster is coextensive with photography and hence with the photographic medium of film. To make this point, he returns more than once in his work to an extended quotation from Marcel Proust's A la recherche du temps perdu, where the narrator happens upon his grandmother and sees her through the eyes of "a photographer who has called to take a photograph of places which one will never see again.” As Kracauer points out in his reading of Proust, the latter compares the photographer here with three types-the witness, the observer, the stranger-whose common trait is a certain distance from the events they perceive; as a stranger, the photographer produces a record that has the power to make strange the reality he records. As Kracauer puts it in a well-known essay published while he was still working on Ginster, the photographic archive "assembles in effigy the last elements of a nature alienated from meaning." 54 Photography, he will write in Theory of Film, is "the product of complete alienation." 55

If photography is partly a product of de-subjectivization, the photographic is defined by what Kracauer calls its "affinity" for the object-world-including the reified human body. The cinema, in Kracauer's realist theory, gravitates toward inanimate objects, things normally unseen, the small and the big: a range of objects that are, for Kracauer, "cinematic because they stubbornly escape our attention in everyday life."56 Betraying an extraordinary debt to Balázs, Kracauer celebrates the cinema for its peculiar ability to zoom in on the physiognomy of things, or what he calls their "psychophysical correspondences." 57 Film is distinguished by its power to isolate fragments of the world, to defamiliarize them and thereby render visible their position within the totality: "The motion-picture camera has a way of disintegrating familiar objects and bringing to the fore ... previously invisible interrelationships between parts of them." 58

In this formulation of Kracauer's film theory, then, we find the resonance of his early novel with its recurring trope of the fragmentary, automatized body. And it becomes apparent that the depiction of Ginster flinging his limbs this way and that shares with photography, as theorized by Kracauer, precisely this tendency to isolate, to abstract, and to reify parts of the human body-a tendency Kracauer

53. On this point, see again Inka Mülder's pioneering study of Kracauer's early works.

54. Kracauer, "Photography," in Siegfried Kracauer, The Mass Ornament: Weimar Essays, ed. and trans. Thomas Y. Levin (Cambridge: Harvard University Press, 1996), p. 62.

55. Kracauer, Theory of Film, p. 16.

56. Kracauer, Theory of Film, p. 53.

57. Echoing Balázs's notion of cinematic physiognomy, Kracauer notes that the "natural objects" represented on film "are surrounded with a fringe of meanings liable to touch off various moods, emotions, runs of inarticulate thoughts; in other words, they have a theoretically unlimited number of psychological and mental correspondences." Kracauer, Theory of Film, p. 68.

58. Kracauer, Theory of Film, p. 54. 
also attributes, in turn, to the treatment of the actor as "an object among objects" in the cinema. ${ }^{59}$

But just as in photography, according to Kracauer, there lies the promise of reconciliation, there is also something redemptive to the reifying stance assumed by Ginster's narrative voice. In keeping with the faint but clearly articulated utopian hope that Kracauer introduced in even his most relentless critiques of modernity during the 1920s, ${ }^{60}$ Ginster operates on a double register. The mildly satirical tone in which the sovereign ego is cut down to size and the world of objects claims its due maps out a "verkehrte Welt," perhaps; but it also intimates an order of things that would no longer conspire against Ginster, tripping him up at every turn.

This order of things-mapped in literature not only by Kracauer but also by authors from Jaroslav Hasek, who created the influential figure of the Good Soldier Svejk, to Franz Kafka, whom Kracauer greatly admired-is precisely the one offered, according to Kracauer's later Theory of Film, by cinema. Just as photography promises a reconciliation between humans and nature, the alienating power of Kracauer's prose consists, as we have noted, in its ability to confront us with our own alienation. ${ }^{61}$ But whereas the grandmother ultimately appears to Proust's narrator completely alienated, "hardly sane, a dejected old woman whom I did not know," Kracauer goes on to theorize the redeeming power of such an alienating gaze-its ability to push through abstraction and alienation, to reconstitute an emphatic notion of experience. Endowed with such a gaze, photography and film have the power to "blast the prison of conventional reality" and open our eyes to what we overlook in our everyday routines. ${ }^{62}$ Arresting though it may be, Kracauer notes, Proust's definition of photography as alienation is ultimately one-sided; it fails to encompass precisely what the subtitle to Theory of Film calls "the redemption of physical reality." As Miriam Hansen suggests, "In the precarious temporality and historicity of photography, its alienation from human intention and control, Kracauer traces a countervailing potential, neither positivistic nor nostalgic, that he believes can be actualized in the medium of film." 63 At stake in what Kracauer calls the "go-for-broke game of photography" is nothing less than this idea of redemption, of reconciliation between humanity and nature; the photographic media contribute to this idea through their powers of reification-by fragmenting and integrating the sovereign subject into the fabric of representation as an "object among objects" and by redeem-

59. Kracauer, Theory of Film, p. 97.

60. See, for example, the essays "The Mass Ornament" and "Photography" in The Mass Ornament.

61. In an incisive essay on Kracauer's enduring relevance as a theorist of the photographic, Lutz Koepnick likewise emphasizes this aspect of his thought: "Kracauer's writings on photography throughout his entire career consider states of alienation as vital playgrounds of human experience, liquefying the reified structures of the bourgeois subject and thus re-enabling the possibility of non-intentional behavior and perception.... [Photography] alienates us from the mechanisms of alienation so as to allow us to cling to the idea of a future reconciliation between humanity and nature, between the rational and the material dimensions of the world" (p. 118). Lutz Koepnick, "In Kracauer's Shadow: Physical Reality and the Digital Afterlife of the Photographic Image," in Culture in the Anteroom, pp. 111-27.

62. Kracauer, Theory of Film, p. 48.

63. Miriam Hansen, "Kracauer's Photography Essay: Dot Matrix-General (An)Archive-Film," in Culture in the Anteroom, pp. 93-110. 
ing the mute material world through the image of its transience. In a hymn to the cinema of Jean Vigo, Kracauer celebrates the way "the camera does not discriminate between human beings and objects, animate and inanimate nature."64

To the reader of Ginster, however, the role of the photographer as a distanced observer and of cinema as a modernist medium of redemption will be familiar as a literary device as well. What critics have described as Ginster's "subject-less-ness" ("Ichlosigkeit") and as the "photographic vision" of Kracauer's novel appears in this light as the narrative approximation of the photographeras-stranger in Proust-as a literary version of photography's intentionless gaze, one in which "what is living appears as atrophied, whereas the material world becomes animated." 65 The narrative voice in Ginster functions as the literary version of the photographic as Kracauer theorizes it in his writings from the late 1920s onward.

A rereading of Ginster, however, also highlights a recurrent fantasy that structures Kracauer's theorizing. Formulated early in the novel as the protagonist's desire to remain "incognito," it is a fantasy of the vanishing subject, the undoing of autonomous, individualized subjectivity, be it in the name of what Adorno would ultimately philosophize as "the preponderance of the object" or of some as yet unrealized-and certainly unnamed-utopia of collectivity. ${ }^{66}$ But whereas in Ginster this subject wishes itself away, wanting to disappear unnoticed from the scene, in Kracauer's major works on film theory, written after the Holocaust, the desire to fade away, let alone to transubstantiate into a "gaseous" form, takes on a completely different valence. After the literal disappearance of, among so many others, Kracauer's mother and aunt at Theresienstadt, the reduction of the subject to a thing-like entity and the fantasy of vanishing into the décor can no longer function in the satiric register of Ginster. And yet, this impetus returns forcefully in all those passages of Theory of Film that invoke the power of cinema to make mute objects speak, to endow them with significance and to subordinate to them the actor or individual as "an object among objects." Whereas Ginster still formulates this de-individuating fantasy from the standpoint of the subject, Theory of Film will locate its relevance on the side of the object-world and physical reality, which film-according to the book's messianic subtitle-has the power to redeem. ${ }^{67}$

Ginster treats the fantasy of becoming an object satirically; Theory of Film, on the other hand, associates the realism of photographic media with melancholia as a form of self-alienation: as Kracauer claims in an aside on "the possible role of

64. "Jean Vigo," Hollywood Quarterly 2, no. 3 (April 1947), pp. 261-63; reprinted in Siegfried Kracauer's American Writings, pp. 47-50.

65. Mülder, Siegfried Kracauer, p. 131. On Ginster's "subjectlessness,” see Jörg Lau, "'Ginsterismus.” On the "photographic vision" of Ginster, see Koch, Siegfried Kracauer, p. 49.

66. For the articulation of collectivity as dream or fantasy in the 1920s, see Barbara Hahn, "Dreams of the Collective-or How to Wake Up," Germanic Review, 87, no. 3 (Summer 2012), pp. 308-18.

67. On the messianism inherent in Kracauer's notion of redemption and its relation to the cabbalist concept of tikkun, see Hansen, Cinema and Experience, pp. 20-23, and Koch, Siegfried Kracauer, p. 139. 
melancholy in photographic vision,"

melancholy as an inner disposition not only makes elegiac objects seem attractive but carries still another, more important implication: it favors self-estrangement, which on its part entails identification with all kinds of objects. The dejected individual is likely to lose himself in the incidental configurations of his environment, absorbing them with a disinterested intensity no longer determined by his previous preferences. 68

As if the exilic subjectivity of this "dejected individual" who has cast off his "previous preferences" were not clear enough, Kracauer goes on to note the close relationship between the melancholic's "kind of receptivity" and the stranger's, thereby referring to a figure who will be central to his arguments about historiography as a profoundly exilic craft in the posthumous History: The Last Things Before the Last.

In the closing pages of Theory of Film, Kracauer both valorizes and tempers this alienated form of "receptivity" by linking the concreteness of the film image and the medium's inherent realism with the question of experience. Thus he reintroduces a humanist perspective into the "thicket of things" that litter the paths of Ginster and the film spectator. ${ }^{69}$ We might say that the fantasy of the vanishing subject is both historicized in relation to the experience of exile and at least partially reformulated by reinstating the individual as the subject of experience at the end of Theory of Film. In this sense, the late Kracauer edges towards the early Balázs, whom he still quotes in the book, and the logic of whose fairy tales he invokes with an anecdote every bit as Orientalist as the tales collected in The Cloak of Dreams: the movie spectator, Kracauer claims, "drifts toward and into the objects-much like the legendary Chinese painter who, longing for the peace of the landscape he had created, moved into it, walked toward the faraway mountains suggested by his brush strokes, and disappeared in them never to be seen again."70

Such dissolution is anathema to Arnheim. Though he shares with Kracauer and Balázs the tropes of exile, his underlying investment is not in a communion with the other or physical reality but in their legibility. When Arnheim reviewed Kracauer's Theory of Film in 1963, he paid tribute to his fellow exile by calling it the "most intelligent book ever written on the subject of film"-but then proceeded to critique the melancholic stance that fueled the "most intelligent" enterprise. As if to evoke Ginster's desire to dissolve, evaporate, and lose his shape, Arnheim titled his review "Melancholy Unshaped" and zeroed in precisely on Kracauer's valorization of melancholia, quoted above.71 Bemoaning the "surrender of the formative capacity of the human mind to the raw material of experience," Arnheim noted-both in culture at

68. Kracauer, Theory of Film, p. 17.

69. Ibid., p. 309.

70. Ibid., p. 165 .

71. Rudolf Arnheim, "Melancholy Unshaped," in Journal of Aesthetics and Art Criticism 21, vol. 3 (Spring 1963), pp. 291-97. Intriguingly, Arnheim had accused Balázs's film theory of being shapeless thirty years earlier, describing it as "a heap" of admittedly intriguing observations that did not, however, "give the reader the stable foundation of knowledge that he desires" (Rudolf Arnheim, "The Spirit 
large and in Kracauer's diagnostic film theory-an "abandonment of pattern" and an encroaching "loss of visibility," which to him bespoke "nothing but the yearning for the unshaped, a return to the raw material of reality." 72

We seem to have returned to the dispute over formalism and realism, the debate between an aesthetics that would redeem physical reality and a theory that would insist on the importance of "interpret[ing] the raw material of experience by means of significant form." Against the background of these theorists' literary works, however, we may now recast this debate by considering these works' structuring fantasies-fantasies of wholeness, of inversion, and of subjectlessness, all powerfully tied to tropes of exile and displacement. What emerges from a reconsideration of these theorists, then, is not merely the common project of elevating the cinema to an art form, let alone of insisting on its specificity vis-à-vis other media. It is also the shared impulse to track the alienating force of the moving image, its power to place even the most essentialized notions of the "soul," of the Weltbild, and of "physical reality" at a critical distance.

By emphasizing the links between the literary and the (film) theoretical, I do not wish to reduce these authors' fictional works to mere prolegomena for their theories. With the possible exception of Eine verkehrte Welt, which is somewhat schematic in its "formula of inversion," these are by no means "theoretical" fictions. And no matter how Chaplinesque Kracauer's hero may have appeared to his readers, these are no "cinematic novels" either, if by that we mean the vaunted "filmic writing" of the 1920s. Rather, as I hope to have shown, these rich literary texts are part and parcel of a broader cultural poetics that their authors develop throughout their entire work. Foregrounding the tropes of distancing, defamiliarization, romantic projection, and inversion, these cultural poetics participate in a larger modernist project inspired by, among others, Georg Lukács's diagnosis of "transcendental shelterlessness"-a trope playfully adopted by Kracauer and Adorno in the 1920s, when they signed a letter to their mutual friend Leo Löwenthal as "agents of the transcendentally shelterless." Without hypostasizing the biographical as a causal, explanatory reference for the literary and theoretical explorations charted in the present essay, I do want to reiterate that for the three classical film theorists discussed here, this notion of homelessness would play out in the lived reality of exile. In a historicizing view, the centrality of dislocation and alienation in their texts should come as no surprise, given the circumstances under which they were developed. In this respect, careful attention to these film theorists' literary production yields new perspectives on the historical position and the imaginative dimensions of classical film theory as a whole.

of Film," in Balázs, Early Film Theory, p. 234). But if he ultimately critiques Balázs for sloppy, if enthusiastic, thinking, Arnheim's critique of Kracauer amounts to an indictment of the latter's aesthetics of indeterminacy, which is not itself shapeless but valorizes shapelessness.

72. Arnheim, "Melancholy Unshaped," p. 296. 